\title{
Re-branding Colombia \\ through Urban Transformation and Rural Regional Marketing
}

\author{
Norberto Muñiz Martínez \\ (iD) https://orcid.org/0000-0002-9954-5486 \\ University of Leon \\ Faculty of Economics and Business \\ e-mail:nmunm@unileon.es
}

\begin{abstract}
Colombia is now projecting a new, positive image to the world after overcoming a past characterised by politically inspired guerrilla warfare and violent conflict with narco-trafficking cartels which had ravaged the country for decades. Even before the country's transformation, other intermediate place institutions - cities and regions - had already taken significant steps towards territorial change and marketing. This paper outlines the processes involved in urban and social transformation in the city of Medellín and in the marketing of the coffee region, as illustrative cases of city re-branding and regional branding, respectively.
\end{abstract}

Keywords: urban transformation, cultural service ecosystem, Medellín, rebranding 


\section{Introduction}

In the modern social-economic globalisation, institutional territories - cities, regions, countries - are seeking good international or national positioning to become better places to live, to attract citizens and tourists, to create investment and exports, to promote certain social-cultural values, etc. In this context, over the last decades, there has been a growing increase in territorial marketing and place branding (Kavaratzis et al.), searching for better visibility and governance.

Marketing emerged as a branch of business management that was focused on the commercialisation of products and services. Over the past years, its principles have also extended towards non-profit entities, as well as in political, sport and cultural organisations. Additionally, marketing is also applied by cities and countries who wish to improve their governance, management and positioning, offering conceptual frameworks to enunciate their exchanges, among the proposals and demands of diverse stakeholders: mainly their citizens, but also tourists and institutions. Cities are connection knots, where diverse flows of exchanges are carried out, be them economic, social, cultural or informational (Castells), in complex networks, among multiple social-economic actors. Some places become brands (Anholt "Foreword"; Anholt "Nation branding"; Lucarelli); cities, regions and also certain natural areas, in relation to specific identities and values.

Although places shows certain parallelisms with business marketing, there are notable differences derived from the public character of cities, regions and countries which are complex social systems among human and institutional groups, especially higher entities such as nations. Frequently, territorial marketing tends to be confused with mere publicity campaigns of a territory, i.e. a place. Marketing should be conceived as an integral framework that this both strategic and of institutional governance; and that the process is established within the place identity, or within its improvements; marketing of solid, singular, cultural or economic content, not simply as propaganda that lacks meaning. Due to this, modern approaches to place branding tend to emphasize processes that are much more orientated toward territorial cultural identity (Kavaratzis and Hatch), instead of mere short term promotional or advertisement campaigns or the creation of logos and slogans (Govers).

Territorial marketing is evolving towards place branding, and it develops through top-down management approaches and marketing plans created by organisations (town halls, federal governments, country ministries, frequently in coalition between these public governments and private organisations such as businesses): toward governance approaches that are much more holistic, participatory and horizontal - bottom-up; thus, re-thinking place branding for cities and regions (Kavaratzis et al.), where the multiple stakeholders that are involved 
in each territory co-create value (Houghton and Stevens; Stubbs and Warnaby; Muñiz-Martínez).

The consolidation of peace in Colombia has paved the way for attracting investments and opening new destinations in the country which were previously unknown even to the Colombians themselves; thus, they can discover the attractions and charms of their own country. The city of Medellín has undergone a more profound process of social and urban regeneration than any other city in Colombia, investing in culture, education, social infrastructure and transport as motors of improving its image. During the 1980s and early 1990s, the violence of the Medellin Cartel wreaked havoc on Colombia's second city. However, at the beginning of the present century, a network of public place administrations, private actors, and social stakeholders embarked on a strategy to transform the city that a decade later has borne fruit, repositioning the image of Medellín very positively.

Meanwhile, a remarkable cultural service ecosystem (Lusch and Vargo) has been created in the coffee region of Colombia that leverages the coffee growing culture and landscape. Based on the theme of agricultural coffee production, a centre for experiential tourism has been created that has emerged as a popular tourist destination in Colombia, second only to the colonial city of Cartagena de Indias. Visitors appreciate the leisure and the opportunity to learn about coffee-growing culture offered in traditional countryside houses set in a beautiful landscape, awarded the World Cultural Heritage status by the UNESCO in 2011, in recognition of the region's cultural and landscape value. Co-branding synergies have been generated between coffee firms in the region: the national umbrella brand Café de Colombia, and the Colombian Coffee Cultural Landscape (Muñiz-Martínez).

\section{Re-imagining Colombia through regional marketing: the Coffee Growing Axis}

Gastronomy, be this based on food or drink, represents a key subject in rural, local, or regional economy (Bessière), for a new development that is both sustainable and has multidisciplinary implications (Rinaldi), which promotes the type of tourism that hunts for experiences of authenticity that link food and place (Sims). Gastronomy has become a growing subject in terms of place branding (Berg and Sevón). In this section, we will analyse interregional marketing in Colombia through the place brand, Coffee Growing Axis, which unites various districts or administration departments, where coffee is harvested. Following its inception, themed tourism was developed in which the visitors looked to experiment and learn the coffee-making process. The Colombian Coffee Cultural Landscape represents an important resource, which adds value both to the production of coffee and 
to the tourism as a sensory landscape. Thus, an ecosystem of coffee services is put together among multiple social actors, with an important sensory component.

The Coffee Growing Axis in an area in Colombia made up by the states of Quindío, Caldas, Risaralda, where high-quality coffee is produced, and where, following this, a large rural tourist attraction was created in traditional coffee country houses, where tourists wished to experiment with the coffee-making process. These elements, included in the framework of the Coffee Cultural Landscape of Colombia ${ }^{1}$ as a World Heritage Site by the UNESCO in 2011, constitute the basis of a notable experience of place branding.

The Colombian Coffee Region, locally called the Coffee Axis, or Eje Cafetero, has created a branding process (Figure 1); evolving from a mere provider of coffee as generic raw material, or a bulk product or commodity item, into a producer of high-quality good, some of them sold as premium or gourmet brands with a higher added value. This is unlike other tropical or semi-tropical commodities such as cocoa and its final consumer product, chocolate, which often tends to be associated with refined business brands from industrial nations (where there are no cocoa plantations), such as Godiva from Belgium or Lindt or Nestlé from Switzerland rather than the country in which the raw material, the cocoa-bean, is produced, e.g. Venezuela (Deshpandé), Ghana, Ivory Coast. However, the coffee branding process is generating wealth and creating value in this Colombian region, contributing to market Colombia as a positively progressing emerging nation.

Similar approaches to agricultural production branding towards gastronomic excellence were developed in the Funen island, Denmark (Askegaard and Kjeldgaard); and, in general, the European Nordic gastronomy of place branding based on culture, terroir (Gyimóthy). Cooperative networks were developed by small local producers and public organisations, so as to create high-quality food service that could serve as an alternative to the mass-produced or manufactured goods by large corporations in the food industry. Similarly, cooperation in the coffee region between small coffee-growers and public organisations has contributed to ensuring that the economic wealth generated from coffee remains in the region, unlike the income drawn by multinationals from other coffee-growing areas of the world that merely provide merely bulk commodity products. Synergies are created among the small coffee brands of that region, the national Brand Coffee of Colombia, represented by the Juan Valdéz character as the ambassador of coffee culture. Thus, the production of certain products is linked with the image of the region or of the country and, particularly, of coffee with Colombia (Kotler and Gertner).

1 Aside from the three districts that make up the Coffee Growing Axis, the área that makes up the Cultural Coffee Landscape is also the North of the Valle del Cauca. 


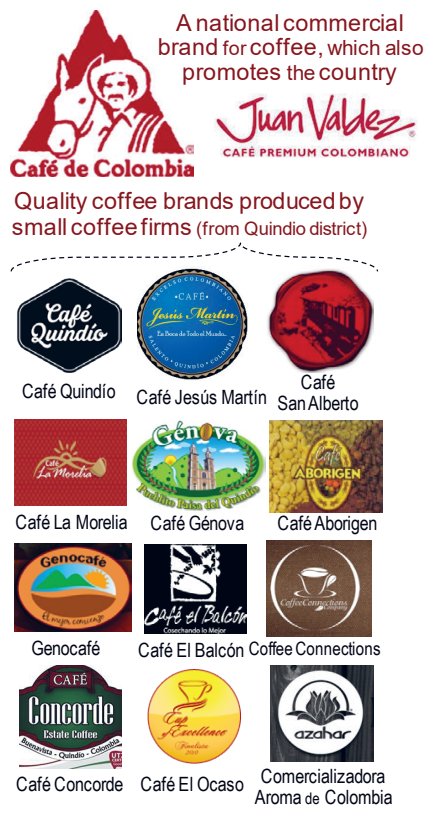

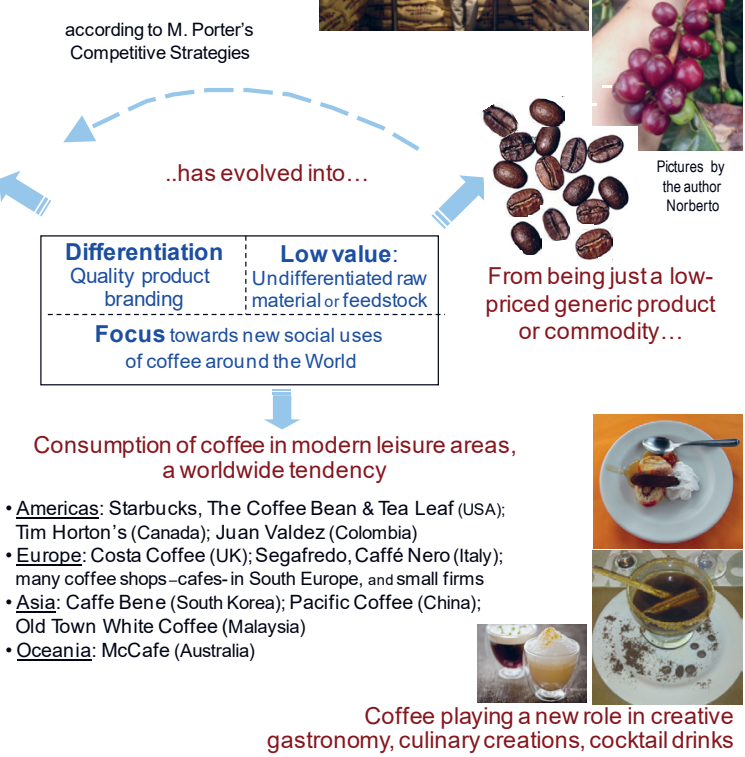

Figure 1. Evolution of coffee positionings from the Colombian Coffee region

During the mid-1990s, in the face of the coffee prices crisis, there was a discussion to abandon coffee agriculture that was subsidised with one million pesos per hectare to destroy all coffee plantations. Luis-Fernando Ramírez-Echeverry, who was the Secretary of Tourism of Quindío at the time, used the rural tourism of France and Spain as a reference, and with the construction of the Coffee Themed Park proposed complementing the coffee business with tourism. To that effect, he travelled to Bogota to propose the initiative to the Ministry of Tourism, but this was rejected; therefore, he started the initiative in his own district. After carrying out market research, he proposed redirecting part of the finance to carry out investments in coffee country houses, which were necessary to accommodate tourists, maintaining the agricultural activity. He invited 20 coffee production companies, with only 12 showing up for the meeting; finally, only two plantations entered his initiative, led by Sonia Montoya in her estate called El Gran Chaparral. Despite the initial scepticism for professionalising for tourist activities the characteristic uses of the hospitality and kindness of the people in the region, the initiative was a success. The following year, another 24 estates were incorporated, with 3,285 visitors; 46 estates in the third year, with 7,918 visitors, which continued to grow until the current amount of over 1,00o estates.

The Coffee Growing Axis, and especially the state of Quindío, is currently a mature tourist destination, with hotels and different types of accommodation. There 
are innovative businesses that combine coffee production and touristic activities falling within this theme. Combia Inspiración offers their visitors the chance to learn the coffee process through an artistic outing through the coffee plantations and coffee tastings; Jesús Martín offers an integral experience from the plantation to the coffee cup (which is hand-selected grain by grain); Café San Alberto (a business that has been internationally awarded several times due to the quality of their quintuple selected coffee) offers their guests tastings on a beautiful terrace with panoramic views of the landscape; Café Quindio, develops state-of-the-art branding in a themed space and restaurant-space; Café Sorrento, a handmade artistic space with a garden area. There are many estates that receive many tourists, such as Salento; others offer traditional living: Filandia or Quimbaya rely on their handmade crafts, while Pijao has joined the network called CittaSlow which promotes a sustainable lifestyle in agriculture, architecture and gastronomy. Thus, a coffee-growing ecosystem has been created among multiple public and private actors at different governmental levels - regional, national and local - and their respective public administrations, as well as coffee growing companies, interacting in a complex coffee service ecosystem with different users - clients and coffee consumers, both individuals or organisations, and tourists looking for sensorial experiences within the coffee growing culture.

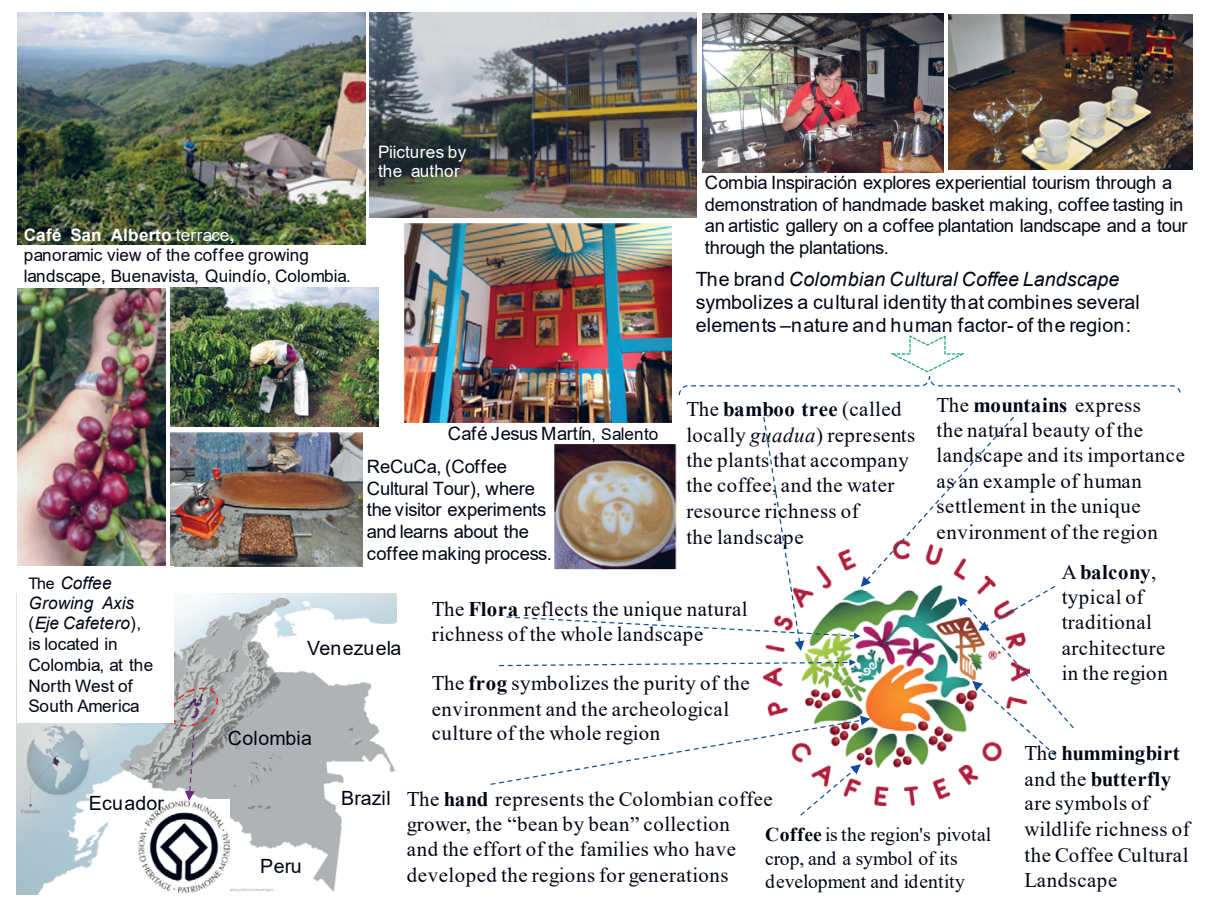

Figure 2. Experiential tourism, in search of authenticity in the Colombian Coffee Cultural Landscape. 
In this coffee-growing ecosystem, a Special Coffee Shop Network (red Tiendas de Café Especial) was created in the Colombian Coffee region in 2017. Based on a market research of the local consumption of coffee carried out in 2016 by the Technological University of Pereira and the consulting firm $7 Q$, led by Ms Angélica-María Rodríguez-García, this project aims to capture the coffee-growing culture, which has been recognized by the UNESCO as a World Heritage, in a simple cup of coffee. The Network is made up of over 20 shops of special coffee. It is considered as specialised coffee, i.e. coffee produced out of coffee grains that have obtained over 84 points in the SCA (Specialty Coffee Association of America) Evaluation. Aside from offering a selection of the finest coffee, expert baristas explain how to prepare and serve it. Therefore, the Network aims to create memorable sensorial experiences, through interactions such as shows and arte latte contests, tastings, filtering method samples, exhibitions of handmade crafts, speeches, songs, poetry, etc.

The Coffee Growing Axis combines the effect of territorial prestige in the business production of coffee, and the development into an internationally famous touristic sub-system in the coffee-growing sector, thus creating an integral place brand. Although agriculture and tourism have already been combined around the world in the agro-food sector (Croce and Perri), tourists are still attracted to discovering the places where a product is grown and understanding its process, as occurs with the production of wine and the wine tourism in the northern hemisphere, e.g. USA, France, Italy, Spain, Portugal, Germany; and in the southern hemisphere, in South Africa, Australia, Argentina or Chile. Notwithstanding, it is not as common to find a similar creation of value in tropical areas of the world, which tend to be the suppliers of prime materials, and the added value is created by multinational brands of industrial countries. The coffee-growing place brand contributes to the value created by coffee remaining in Colombia.

\section{The transformation and international branding of Medellín, at the Colombian urban vanguard}

This section will analyse the notable transformation and branding of the city of Medellin, which has led the processes of urban change in Colombia through the constructions of cultural and educational infrastructures, and its inclusive transport. After unfavourable times in the past decades, having suffered from the violence of drug trafficking and the crimes involved in this, as well as the consequences of the dislocations during the armed political conflict that the country had suffered from for half a century, the city undertook integral urban solutions that are now a point of reference in South America and, in general, in all of the LatinAmerica region. Because of this, Medellin was appointed as the most innovative 
city in the world in 2013 by The Wall Street Journal (USA), thus renovating its image and city brand.

The city holds a metropolitan area of almost 4 million citizens; the second most important number in Colombia after the capital of the country, Bogota. It is the capital of a region with a strong sense of historical identity (Antioch in Colombia). Unquestionably, aside from a tangible physical-urbanistic dimension, the territories become places through social interactions and human affective engagements, grounded in the historical-cultural links that represent emotional ties to a city (Florek), region or nation. The ex-mayor, Mr Sergio Fajardo had a vision of channelling human and institutional emotions within civil society, into moments of social impulses.

\section{Socio-historical context in which Medellín began a city re-branding process}

Medellin is the Colombian city that has most probably experimented with the most notable improvements in terms of management and promotion during the last decade. Along with Cali, the capital of the Cauca Valley, it suffered from the violence of drug trafficking which negatively affected its reality and image for a long time. Although the reality of Medellin had already changed during the mid-199os, the image of the city was influenced by the negative image of violence in its aftermath. Because of this, integral governance and branding were key in helping the exterior perception evolve toward a more positive image.

Medellin had a strong but negative image; the problem was how to analyse it to change that image (Gertner and Kotler). In this context, in 2004, the International Forum City Marketing Medellin was organized to analyse and debate how to implement an improvement. The Author of the paper, who was invited to deliver a keynote presentation at this symposium, recommended that the city got involved in organising events that would provide a positive reputation (until then, the only thing created was negative notoriety). That year, the III International Congress of the Spanish Language was held in Rosario (Argentina), and the following one was going to be held in Cartagena de Indias (Colombia). This event has international coverage, with the presence of the international media and Spanish speaking authors, as well as heads of state and governments; but while Cartagena was already famous for its historical beauty and for being a UNESCO World Heritage Site, it was underlined that the congress would be more important for Medellin in terms of creating good news for the city. Therefore, in 2007, Medellin co-organised the conference in which the Spanish Language Grammar was unified; and in Cartagena, the congress in which a tribute to the Colombian author and Nobel Prize for literature, Gabriel Garcia Marquez, was carried out. It was a complete success, with 
citizen participation and international coverage. The King and Queen of Spain visited the city, inaugurating the Spanish Library in the suburbian area or township of Santo Domingo. Medellin finally began to generate positive news after the negative times related to the Cartel of Medellin and the violence of drug trafficking.

Why Medellín needed it to undertake the re-branding of the city

Because there was a big difference between the city image ant its realty

Image

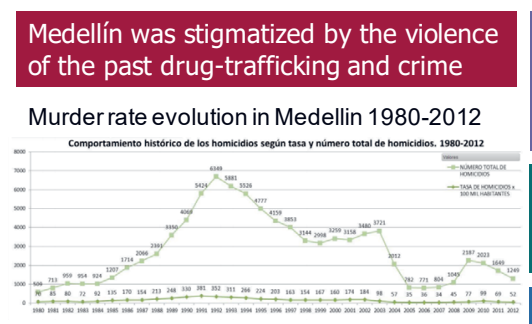

Source: Gil Ramirez, M.Y (2013), “Medellin 1993-2013: Una ciudad que no logra encontrar el camino para salir definitivamente del laberinto". Woodrow Wilson International Center for Scholars, Washington D.C.

Medellín, the most educated; city motto based on culture
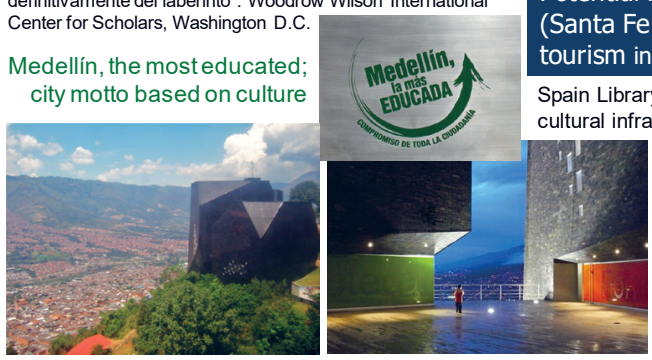

Reality

Dynamic and entrepeneur city:

- Trade shows and congresses: Colombia Moda,

AgroFuturo Expo, decoration -Feria Home-, health

-trasplants, dentristy-. Sports and cultural events

Universities, Poetry Festival, arts (Fernando Botero, a

figurative artist and sculptor); music: Carlos Gardel (Tango music eminent singer), Juanes (pop music singer)

Privileged weather: "city of eternal springtime"

Potential rural tourism, ecotourism, heritage villages (Santa Fe de Antioquia, Guatapé); coastal and beach tourism in the Caribean-Urabá and Pacific-Chocó areas

Spain Library Park (Parque Biblioteca España) represents a key ultural infrastructure to improve the living conditions of slums

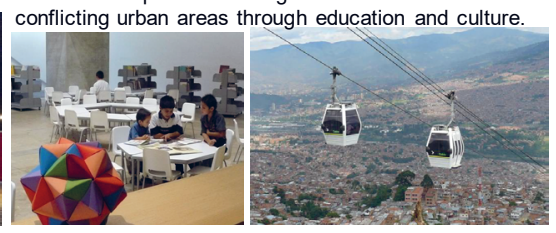

Figure 3. Differences between the image and reality of Medellin, from the beginning to the end of the 1990 and 2000 .

The library was co-financed by the Spanish international cooperation. The United States also cooperated with Medellin, as a part of the American Geographical Society's Bowman Expedition program, focused on the social change in poor neighbourhoods, in particular the slum called "Comuna 13" (Drummond, et al.). This program's goal was to improve the security, development and infrastructure in the area. On the other hand, in 2009, the project "Medellin, the Most Educated" was awarded the 1st edition of the City to City Barcelona FAD Award (Spain). The award was collected by the ex-mayor Sergio Fajardo, and it acknowledges the value of a plan of infrastructure and programs related to education and culture, which contributes to pacification, social integration and the improvement of lifestyle in Medellin.

In 2010 Medellin organised the Pan-American Games of 2010. Through such events, the city began the process of improving its image on an international scale 
that still continues today. Medellin is one of the cities in the world whose image has differed the most with regards to its reality; because of this, a good branding approach was important, to be guided by social inclusive governance and branding that created a positive image. With regards to the infrastructure, Medellin was a pioneer in Colombia, building the first and only subway in the country; it has a great convention centre that organises numerous congresses, and it is the headquarter of businesses and multinationals in Colombia. It is a dynamic and entrepreneurial city, with universities and healthcare that is renowned for its surgery and transplants; it has emerged as the cluster of fashion and design. In international cooperation or city benchmarking, Medellin established an alliance with Barcelona, internationally renowned for its transformation model and urban promotion.

At present, the city is witnessing a wave of new cultural revitalisation, such as culinary and gastronomic creativity (Londoño and Medina), and literature events of international scope with several world languages, such the annual Medellin Poetry Festival which debates and divulges poetic and expressive tendencies, and is carried out in theatres and auditoriums, some of these open-air, in the metropolitan parks around the city. The festival has also won a Spanish literary award for its contribution to peace (Arias). The city also organises a Book and Culture Festival, which, in its 11th edition, attracted over 450,000 visitors with different activities, such as editorial launches, conferences and meetings between authors and readers (Manetto).

\section{Medellín's transformation reaches international reputation}

Given its notable urban regeneration, Medellin attracts the international interest of the media. The New York Times states that many of the once marginal slums have been transformed through some amazing architectural works, like the Biblioteca España (Spain's Library), a modern public library and community space up on the hills of the low-income Santo Domingo neighbourhood (McShane). The city's Metrocables (aerial gondola lift implemented system) and outdoor automatic escalators of nearly 400 metres, developed to integrate the poor hillside neighbourhoods with the city centre, are innovative solutions in public transit. This transport system carries 30,000 people daily and connects into the Medellin's Metro. New educational and cultural spaces and greenery parks provide the city with social infrastructure.

The plan to bury almost $400 \mathrm{~m}$ stretch of highway along the Medellín river is ambitious, to build a park and open spaces on the top surface. Similar renovation projects have been developed in such cities as Seoul - Cheonggyecheon River - (South Korea), Madrid-Rio (Spain), the "Big Dig" in Boston (USA), the Avenida Colombia tunnel 
in the Colombian city of Cali; and also waterfronts renewals: Barcelona for the Olympic Games 1992, the Porto Maravilha project for the Rio de Janeiro 2016 Olympics, Puerto Madero in Buenos Aires. These are all cities that have rethought their highways and waterfronts for the benefit of public space. Certainly, urban change stands out in Latin American's capitals -Bogotá, Mexico City, Lima, Montevideo, Santiago de Chile; and also in medium-size and non-capital cities.

Due to this transformation, in 2016, Medellin received the Lee Kuan Yew Award, an award which is considered to be the Nobel Prize of Urbanism, and which is awarded biannually by the Urban Redevelopment Authority Singapore and the Centre for Liveable Cities to promote urban innovation and sustainable development. Since 2010, the award bears the name of Lee Kuan Yew (1923-2015) who was the Prime Minister of Singapore and globally positioned this city-state. 38 other cities from around the world competed; among them, those that received an honorary award were Auckland (New Zealand), Sidney (Australia), Toronto (Canada) and Vienna (Austria).

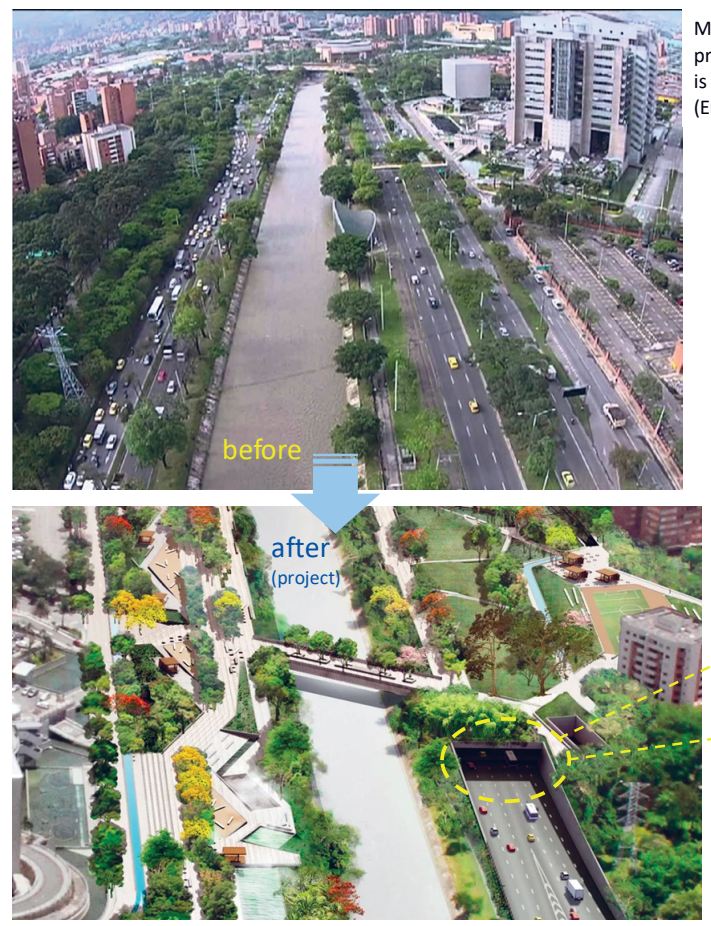

Medellín River surrounded by highway sides, which prevents walking along the riverside. Building to the right is EMP -Medellín Public Corporation Businesses(Empresas Públicas de Medellín).

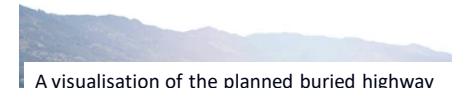
(to the right of the river). Photograph: Latitud

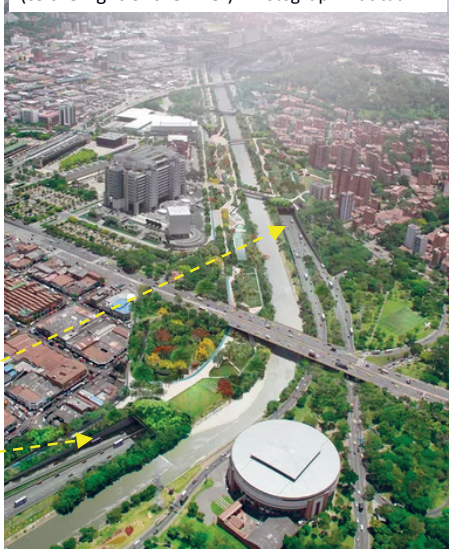

A visualisation of Medellín's plan to bury its highway and build a park. Photograph: Alcaldía de Medellín

Figure 4. Plan to bury a stretch of highway along the Medellín River, to provide green space for citizens' leisure.

The projects that Medellin presented, and for which it won the award, were three: the Wrap Around Garden, a green metropolitan fringe that connects surrounding 
the areas of the Comuna 8 with garden spaces and pedestrian pathways; the River Parks, to recuperate and integrate the Medellin River into the city as a meeting point; and the Articulated Life Unites that are civic-social centres in the suburbs to promote sport and culture. The judges of the award said about Medellin:

The key for its transformation is a daring and visionary leadership, as well as social and urban innovation. The chosen leaders showed strong political will and commitment to good government, citizen participation and equal opportunities for all citizens. Despite having limited resources, they creative and unconventional approaches were taken to deal with difficult problems. Medellin focused on education and culture to achieve changes on a smaller, but efficient, scale; with high impact urban projects that have transformed their communities and the city in a short space of time" ("Medellin").

With this transformation, Medellin leads the transformation process in its country, and is considered as avant-guard, and maybe even ground-breaking, due to the positive resolution of the violent conflicts it has suffered from. This city is a point of reference in Latin-America, along with other American cities, like the Ecuadorian Guayaquil, with its urban regeneration, the North-American Vancouver (Canada) with its environmental management, or the avant-guard example of San Francisco and the cluster of the ICTs in Silicon Valley; the South American Curitiba (Brazil) with its environmental management and citizen participation or the urban regeneration of the fluvial front of the Parana River in Rosario (Argentina), among others.

\section{Conclusions}

Colombia is a country that opens to the world, and presents a new, positive reality after decades of having suffered from political armed conflicts and violence from criminal groups. Its urban and regional experiences are in the vanguard of the social-economic development of the country. Such are the creation of the coffee-growing ecosystem and its consolidation as an experiential tourist destination; as well as the great urban and social transformation, and the branding in the city of Medellin. These processes contribute to promoting the country as a whole.

The synergies between business branding and place branding of the Coffee Growing Axis can be an example to emulate for other emerging regions, located in (semi)tropical areas, to create value through quality local productions, which can be internationally commercialised, and also could be a sector for tourism. The development of the brand Café de Colombia and Juan Valdez, and brands from smaller companies of quality coffee, leads in the direction of the image improvement of Colombia, its cities, and its regions. Also, Colombian coffee can have a role around the planet, as a drink and cocktail in modern leisure spaces, places of social gathering and cosmopolitan 
lifestyles; as well as in relation to the new gastronomic creativity. The co-creation of value in the Coffee Growing Axis and the social-economic culture that it represents obtained international support through the award of the Colombian Coffee Culture Landscape as a World Heritage Site from the UNESCO; with the consequent fame that this gives. It is important to preserve the Coffee Culture Landscape, not only of that region but also of cities like Armenia (capital of the state of Quindío), because this is what makes it unique, with the panoramic landscape view from the city, which is currently in danger from uncontrolled urbanisation.

Large urban areas are being formed around the world, whose connectivity is creating new, worldwide geopolitics, alongside those of the states-nations; the processes that are now a global reality (Khanna). Along with the largest urban groups in the world and the global cities, second-tier cities have also emerged, being the centre of sub-national geographic areas, with notable urban processes, of international or sub-regional importance. In this sense, Medellin is a city that represents a positive example in the world for having overcome violent conflict, and or marketing-city repositioning with innovate urban and social solutions.

Integral marketing of cities, regions or countries, should focus on the cultural identity of each territory, and find a creative differentiation of place brand, much more than a mere exterior promotion through a short term advertisement campaign, a motto or slogan and a logo. Place branding should not be only about tourist promotion, which is one of the many urban exchanges. The key is adequate communication with all of the stakeholders involved in the city, notably the citizens themselves, as well as tourists and other visitors and customer organisations. The cities should aim to achieve a lifestyle for their citizens through the improvement of infrastructure and public services, social integration; they should be attractive to visit and should also stress innovative values of creativity, excellence and urban design. Multidisciplinary approaches are needed in urbanism, sociology, economy, environment and culture. Aside from being better places to live, the cities and territories compete in different sector concepts, and some places become brands in accordance to their respective identities.

The author wishes to acknowledge Mr Luis-Fernando Ramirez-Echeverry for his visionary leadership in creating the tourism sub-system to the coffee ecosystem, and thank him for his valuable guidance in allowing this research; and Ms AngélicaMaría Rodríguez-García, who is consulting in Sustainable Tourism, and manages the network of shops "Café Especial en el Paisaje Cultural Cafetero Colombiano", she is lecturing at the Universidad Tecnológica de Pereira (Colombia), and holds a Master's degree in Marketing, Universidad Complutense de Madrid (Spain). In Medellin, the author would like to thank Mr Uriel Sánchez and Mr Juan Leonardo Correa for their cooperation in the process of analysing and marketing the city. 


\section{Works Cited}

Anholt, S. "Foreword to Special Issue of Brand Management." Place Branding 9 (2002): 238-249.

Anholt, S. "Nation Branding: A Continuing Theme." Journal of Brand Management 10.1 (2002): 59.

Arias, S. "El Festival de Poesía de Medellín, premio «Aula de las metáforas»", La Nueva España 28 Jun 2013, city of Oviedo newspaper, Spain. Retrieved http:// www.lne.es/centro/2013/06/28/festival-poesia-medellin-premio-aula/1434487. html

Askegaard, S., and D. Kjeldgaard. "Here, There, and Everywhere: Place Branding and Gastronomical Globalization in a Macromarketing Perspective." Journal of Macromarketing 27.2 (2007): 138-147.

Berg, P. O., and G. Sevón. „Food-branding Places - A Sensory Perspective.” Place Branding and Public Diplomacy 10.4 (2014): 289-304.

Bessière, J. "Local Development and Heritage: Traditional Food and Cuisine as Tourist Attractions in Rural Areas." Sociologia Ruralis 38.1 (1998): 21-34.

Castells, M. The Rise of the Network Society. Oxford: John Wiley and Sons, 2011.

Croce, E., and G. Perri. Food and Wine Tourism: Integrating Food, Travel and Territory. Wallingford: CABI, 2010.

Deshpandé, R. "Why You Aren't Buying Venezuelan Chocolate." Harvard Business Review 88.12 (2010): 25-27.

Drummond, H., et al. “Medellin: A City Reborn?” FOCUS on Geography 55.4 (2012): $146-154$.

Florek, M. "No Place like Home: Perspectives on Place Attachment and Impacts on City Management." Journal of Town \& City Management 1.4 (2011): 346-354.

Gertner, D., and P. Kotler. "How Can a Place Correct a Negative iImage?” Place Branding 1.1 (2004): 50-57.

Govers, R. "Why Place Branding Is not about Logos and Slogans." Place Branding and Public Diplomacy 9.2. (2013): 71-75.

Gummesson, E. "From One-to-One to Many-to-Many Marketing." Proceedings from QUIS 9. Karlstad. Eds. B. Edvardsson, et al. Sweden: Karlstad University, 2004.

Gyimóthy, S. “The Reinvention of Terroir in Danish Food Place Promotion.” European Planning Studies, 25.7 (2017): 1200-1216.

Houghton, J. P., and A. Stevens. "City Branding and Stakeholder Engagement." City Branding: Theory and Cases. Ed. K. Dinnie. Basingstoke: Palgrave Macmillan, 2010, pp. 45-53.

Kavaratzis, M., and M. J. Hatch. “The Dynamics of Place Brands: An Identity-based Approach to Place Branding Theory." Marketing Theory 13.1 (2013): 69-86.

Kavaratzis, M., et al., eds. Rethinking Place Branding: Comprehensive Brand Development for Cities and Regions. Heidelberg: Springer, 2014. 
Khanna, P. Connectography: Mapping the Future of Global Civilisation. New York: Random House, 2016.

Kjeldgaard, D., and J. Ostberg. "Coffee Grounds and the Global Cup: Glocal Consumer Culture in Scandinavia." Consumption, Markets and Culture 10.2 (2007): 175-185.

Kotler, P., and D. Gertner. "Country as Brand, Product, and Beyond: A Place Marketing and Brand Management Perspective." Journal of Brand Management 9. 4/5 (2003): 49-61.

Londoño, M. D. P. L., and F. X. Medina. "Effects of Cultural and Tourism Policies on Local Development: The Case of Food Trails in Medellín, Colombia." Almatourism-Journal of Tourism, Culture and Territorial Development 8.7 (2017): 89-106.

Lucarelli, A. "Co-branding Public Place Brands: Towards an Alternative Approach to Place Branding. Place Branding and Public Diplomacy 14.4 (2018): 260-271.

Lusch, R. F., and S. L. Vargo. Service Dominant Logic; Premises, Perspectives, Possibilities, Cambridge: Cambridge University Press, 2014.

Manetto, F. "Medellín, de capital de la cocaína a centro americano de las letras; La Fiesta del Libro y la Cultura se convierte en un símbolo de superación de la ciudad.” El País 19 Sep 2017, newspaper, Madrid, Spain. Retrieved https://elpais. com/cultura/2017/09/18/actualidad/1505720817_997583.html

“Medellín, Colombia conferred Lee Kuan Yew World City Prize 2016" Retrieved https://www.nas.gov.sg/archivesonline/data/pdfdoc/20160316004/URA\%20pr1616(LKYWCP2016).pdf

McShane, N. "Urban Renewal with Innovative Architecture and Design", The New York Times on-line 21 Dec 2015. Retrieved http://www.nytimes.com/ interactive/2015/01/11/travel/52-places-to-go-in-2015.html?_r=2

Muñiz-Martínez, N. “Towards a Network Place Branding through Multiple stakeholders and Based on Cultural Identities - the Case of 'The Coffee Cultural Landscape' in Colombia." Journal of Place Management and Development 9.1 (2016): 73-90.

Rinaldi, C. "Food and Gastronomy for Sustainable Place Development: a Multidisciplinary Analysis of Different Theoretical Approaches." Sustainability 9.10 (2017): 1748.

Sims, R. "Food, Place and Authenticity: Local Food and the Sustainable Tourism Experience." Journal of Sustainable Tourism 17.3 (2009): 321-336.

Stubbs, J. and G. Warnaby. "Rethinking Place Branding from a Practice Perspective: Working with Stakeholders." Rethinking Place Branding: Comprehensive Brand Development for Cities ad Regions. Eds. M. Kavaratzis, et al. Heidelberg: Springer, 2015, pp. 101-118. 
Norberto Muñiz-Martínez - Associate Professor of Marketing at the University of Leon, Spain. He has taught courses on new trends in tourism in different cities of Mexico and Colombia and doctoral courses in Brazil and Venezuela. Visiting professor at the Asia-Europe Institute, University of Malaya (Kuala Lumpur, Malaysia) and Universidad de Medellín (Colombia); he also cooperates with Stockholm University Business School (Sweden). He has conducted research \& cooperations with cities and organizations in Colombia, Mexico, Argentina, Venezuela and Spain. Member of the Latin American Association on Place Marketing and Urban Development and the International Place Branding Association. His areas of research are: city marketing \& place branding, strategic marketing and retailing, new trends on tourism (eco-tourism and exploration travelling), and the emerging new Marketing paradigm - Service Dominant Logic. 